\title{
Poeticizing A Story of Asylum: Refugees, Refuge, and Refuse
}

\author{
Nicholas Ng-A-Fook \\ University of Ottawa \\ nngafook@uottawa.ca
}

\begin{abstract}
...the foreigner is first of all foreign to the legal language in which the duty of hospitality is formulated, the right to asylum, its limits, norms, policing, etc. He has to ask for hospitality in a language which by definition is not his own, the one imposed on him by the master of the house, the host, the king, the lord, the authorities, the nation, the State, the father, etc. This personage imposes on him translation into their own language, and that's the first act of violence.
\end{abstract}

(Derrida, 2000, p. 15)

Today, Rohingya refugees continue to flood across the Ganges-Brahmaputra Delta from Myanmar to Bangladesh. For many of them, there is no promise of return, of reprieve, of refuge, as they seek asylum from religious persecution. There are no homes, only hospital rooms and hallways awaiting the wounded and injured. These are the news headlines on TV. In a posttruth era of poll-I-ticking, liking, loving, emoji-ing, tweeting, we are, our family, myself included, failing to witness what Solnit (2013) calls elsewhere the stories of lives faraway, nearby.

Our old Uncle Sam has imposed an executive order, imposing limits, norms, and the policing of migrants' international rights. And yet, he is not alone in ordering and policing the international rights of immigrants, migrants, and refugees. The crows perched back-to-back, in Carol Lee's collection of poetry, keep tall watch, in silence as they scan for refuses of refugees sneaking, sometimes openly, across our USA-Canadian borders. Here in Canada and abroad in countries like Germany, old stock settlers are outraged at the possibilities of opening their borders unconditionally to Syrian and Haitian refugees.

Asylum seekers from Afghanistan, Iraq, Syria, Libya, Somalia, South Sudan, Eritrea and elsewhere, displaced by American foreign incursions, civil wars, religious and tribal conflicts, have sought refuge on the shores of countries like Italy and Greece. They continue to travel perilously seas by boat, taking a momentary pause to then hike across the mountains, over land, seeking hospice and the promises of a more hopeful future in nation-states like Sweden, the United Kingdom, and Germany. In a 2014 United Nations High Commission for Refugees (UNHRC) report, we learn that 59.5 million people were forcibly displaced from their homelands. ${ }^{1}$ We are, according to the UNHRC, a world at war.

In 2015, Germany opened its borders to all Syrian refugees to alleviate the migration crises taking place on the shores of southern Europe. Perhaps it was remembering the global violence caused by WWII, or the tearing down of the Berlin Wall, that pushed the German government to put the refugee policies outlined in their 1985 Schengen Agreement with other European countries on hold. ${ }^{2}$ Or, perhaps more pessimistically, or pragmatically, they sought to increase their shrinking workforce. ${ }^{3}$ Regardless of their political intent, opening up of their 
borders put pressure on other EU countries who used a "1990 protocol as the legal basis for refusing to take any share of the refugees from the Middle East and Africa" who were then "pouring into Europe to escape war, oppression or famine."4 Germany's policy of unconditional hospitality forced members of the Schengen Agreement, to take what Derrida (1992) called in his reflections on Europe, the other heading. "Something unique is afoot in Europe even if we no longer know very well what or who goes by this name. Indeed, to what concept, to what real individual, to what singular entity should this name be assigned today? Who will draw up its borders" (Derrida, 1992, p. 5)? The trials and tribulations of Brexit (Britain's exit from the European Union's drawing of itself) illustrate such differing navigational headings. ${ }^{5}$

In her collection of poems, No Return, Carol Lee draws on cultural, pedagogical-indeed, poetic - inquiry, to disrupt the violent curricular colonizing grammars of distancing and silencing. She articulates the often inarticulate effects of displacement, di-s-appearances, aggression, memories of violence, literacies of looting, poverty, tyranny, dying, executions, mending of souls, the deep scars of bodies crumpling like rag dolls into soft heaps, wading the tides of dislodged travellers to catch the last boat, escaping bomb after bomb after bomb, bartering life savings for safe passage, trying to muster a smile that "I" once was, old, young and now lost upon arrival. Her poetry speaks back to the "right/eous" political propaganda calling to end a foreigner's rights to the laws of unconditional hospitality. No Return challenges us to examine these values and to question whether or not our nation-states are doing enough for refugees.

In her explanatory article to No Return, Carol calls on us, to use "all the tricks of language and story...to deconstruct and construct meaningful nuances with the words and plots." She invites us in to her poetic collection of "creative practice," of re-storying, that in turn challenges "readers' thinking or rethinking" as a form of "critical pedagogy," teaching us how "crafting language" as a "creative pedagogy" works on us as writers, as an aesthetics of "critical practice," what she calls an ethics of "thinking critically" in our day-to-day inter/actions with others faraway, nearby. Carol draws on the arts, arts-based research methodologies, to document and re-story the migratory lived experiences of a refugee. Here Solnit (2013) reminds us,

We tell ourselves stories in order to live, or to justify taking lives, even our own, by violence or by numbness, and the failure to live; tell ourselves stories that save us and stories that are quicksand in which we thrash and the well in which we drown, stories of justification, of accursedness, of luck and star-crossed love, or versions clad in cynicism that is at times a very elegant garment (p. 3).

Carol's thoughtful collection of poetry calls upon educators, educational researchers, and public intellectuals to respond to the ongoing refugee crisis as strong poets. As we have stressed elsewhere, "to educate as a strong poet...requires a vision, an imagination, an intense desire for social change, a faculty of reason, and a talent for speaking differently" (Ng-A-Fook, Ibrahim, Reis, 2016, p. xxi). Carol's poems force one to listen and in turn speak differently to the current news headlines on TV or social media in an era of post-truth poll-I-ticking. Her critical call for the arts, the call for us to contemplate and reconsider the lived experiences of "refugees," is a call to story our cultural and pedagogical inquiries differently.

Cultural and Pedagogical Inquiry, Fall 2017, 9(2), pp. 1-3

ISSN 1916-3460 C 2017 University of Alberta

http://ejournals.library.ualberta.ca/index.php/cpi/index 


\section{References}

Antenore, B. (2016). Can the Schengen Agreement survive the EU refugee crisis? (2/18). Retrieved September 27, 2017, from https://www.europeaninstitute.org/index.php/ei-blog/276-february-2016/2129-can-theschengen-agreement-survive-the-eu-refugee-crisis-2-18

Derrida, J. (1992). The other heading: Reflections on today's Europe. (P-A. Brault \& M. B. Naas, Trans.). Indianapolis, Indiana: Indiana University Press. (Original work published 1991).

Derrida, J. \& Dufourmatelle, A. (2000). Of hospitality. (R. Bowlby, Trans.). Stanford, California: Stanford University Press. (Original work published 1997).

Ng-A-Fook, N., Ibrahim, A., \& Reis, G. (2016). (Eds.). Provoking curriculum studies: Strong poetry and arts of the possible in education. New York, New York: Routledge.

Hall, A., \& Lichfield, J. (2015, August 24). Germany opens its gates: Berlin says all Syrian asylum-seekers are welcome to remain, as Britain is urged to make a "similar statement." The Independent. London.

Johnson, I. (2017, June 21). Brexit: Anti-immigrant prejudice major factor in deciding vote, study finds. The Independent. London.

Reuters. (2015, September 10). There's a very practical reason why Germany is taking in so many refugees. Business Insider. New York.

Solnit, R. (2013). The faraway nearby. New York, New York: Viking Penguin.

UNHCR. (2015, June 18). Worldwide displacement hits all-time high as war and persecution increase. The UN Refugee Agency.

\footnotetext{
${ }^{1}$ See http://www.unhcr.org/news/latest/2015/6/558193896/worldwide-displacement-hits-all-time-high-warpersecution-increase.html.

${ }^{2}$ See https://www.europeaninstitute.org/index.php/ei-blog/276-february-2016/2129-can-the-schengen-agreementsurvive-the-eu-refugee-crisis-2-18

${ }^{3}$ See $\mathrm{http}$ ://www.businessinsider.com/r-in-ageing-germany-refugees-seen-as-tomorrows-skilled-workers-2015-9

${ }^{4} \mathrm{See}$ http://www.independent.co.uk/news/world/europe/germany-opens-its-gates-berlin-says-all-syrian-asylumseekers-are-welcome-to-remain-as-britain-is-10470062.html.

${ }^{5}$ See http://www.independent.co.uk/news/uk/politics/brexit-racism-immigrant-prejudice-major-factor-leave-votewin-study-a7801676.html
} 